\title{
Research on the Problems and Countermeasures of China's Financial Subsidy
}

\author{
Zhenyan Wang \\ Department of Economic Management, School of North China Electric Power University, Baoding \\ 071003, China \\ 2052346317@qq.com
}

Keywords: Financial subsidies; Current situation; Policy

\begin{abstract}
As the lever of China's government to regulate the economy, financial subsidies play an active role in making up for market defects, regulating supply and demand structure, promoting industrial policies and implementing price reform. Financial subsidies are free subsidies or allowances given to certain specific enterprises, residents or matters by the state finance according to needs. It has distinctive policy, flexibility and timeliness characteristics. Through financial subsidies, the government will transfer part of the unpaid income from the society to some enterprises or residents for free, regulate the material interests of enterprises and residents, and use them well to play an active role in promoting economic development, if use incorrectly, which puts the country on a heavy financial burden. At the same time, China has joined the World Trade Organization. Therefore, in the face of the new domestic and international environment, how to improve the effect of financial subsidies and play an active role in financial subsidies has become an important issue in fiscal and economic work. Based on the research on the current situation of financial subsidies, this paper analyzes the problems of China's financial subsidies and puts forward suggestions for improving China's financial subsidy policy.
\end{abstract}

\section{Introduction}

In real life, whether it is the people's food, clothing, housing and transportation, or the country's political and economic activities, it is inseparable from the financial, socialist and market economy environment, which determines that we cannot live without financial subsidies. As far as families and residents are concerned, hospitals where one person is born, kindergartens in early childhood, schools that enter primary school and even enter middle school and university during school age, although vigorously advocate and encourage the development of private undertakings after the reform and opening up, the current After the government participates in the work, once it is temporarily unemployed, it can rely on the relief provided by the government to maintain its life; when entering the retirement age, it can rely on the government to participate in the provision of old-age social insurance and medical insurance, etc., all of these, etc. They are inseparable from government and financial services.

\section{Analysis of the status quo of China's financial subsidy policy}

The scale of financial subsidies is large and the projects are mixed.

From the perspective of China's policy subsidy expenditure, there are grain and cotton oil price subsidies, price subsidies, meat price subsidies, and other price subsidies. A wide variety and scale expansion. National policy subsidies expanded from 1.14 billion yuan in 1978 to 104.228 billion yuan in 2000. According to relevant information, the policy subsidies in 2004, 2005 and 2006 were as high as 79.58 billion yuan, 98.847 billion yuan and 138.752 billion yuan respectively, with growth rates of $28.92 \%, 25.47 \%$ and $38.96 \%$ respectively. At present, all aspects of production and consumption are subsidized, not only in a wide variety of names, but also in a wide range and in various forms. According to the receiving object, it can be divided into: subsidies for production links such as industry, agriculture, urban public enterprises, subsidies for circulation of commerce, grain, etc., subsidies for employees or residents, and subsidies can be divided into: price subsidies 
and loss subsidies. , living allowances for workers, interest subsidies, and other subsidies. With the expansion of subsidies in China, the link of financial subsidies has developed into production, circulation, and consumption, and forms a ubiquitous pattern of subsidies. The financial subsidy project is too wide and the amount is too large, which has caused many problems. The expansion of financial subsidies has affected the country's fiscal balance and created an unnecessary burden on the finances. The scope of subsidies is too wide, which weakens the decisive role of the market in resource allocation and interferes with the effective operation of the market economy.

\section{Unreasonable understanding of financial subsidies}

On the one hand, it is the nature of financial subsidies. It has long been used as a political lever. It has not exerted the economic life adjustment function of economic leverage. As a result, the financial subsidy rigidity is excessive, which affects the growth of fiscal revenue and even exceeds the state's financial affordability. On the other hand, it is the status of financial subsidies. Financial subsidies are aimed at the relatively big problems in economic life. In order to ensure the healthy development of the economy and the stable development of society, the shortage of funds in the economic structure is balanced by means of redistribution of funds, but in recent years The economy and society that have come to China have entered a stable and rising development track. The types, scope and amount of subsidies are still increasing in terms of financial subsidies, which makes the financial rigidity more and more serious.

\section{The policy arrangement of financial subsidies is not reasonable enough}

The first is that the pricing is unreasonable. The pricing of the products does not combine the actual prices of the products. The business accounting does not clearly distinguish between parity and bargaining. The retention and subsidies are rising simultaneously, which causes the financial subsidies to be lost in the middle of the business. Secondly, the investment is unreasonable. It is not clear whether the loss of the enterprise belongs to the nature of the operation or the nature of the policy. The subsidy is treated equally, causing some enterprises to rely excessively on financial subsidies. The reported costs and benefits are not true, making it difficult for enterprises to launch fair competition. The objective principle of production development is intensifying the contradiction between market supply and demand. Once again, the subsidy method is unreasonable. The financial department adopts the method of fiscal write-off for operating losses and policy losses, and adopts the method of actual reimbursement, which causes the subsidies to be out of control. For example, some subsidies adopt the method of clearing up, and eventually become a kind of enterprise. The fixed income has caused the subsidy to be rigid and lost the original fiscal adjustment.

\section{Financial subsidy management is imperfect}

First of all, the imperfection of the system, the subsidy subject and the subsidy channel are not clear, and there are phenomena of increasing the subsidy program and the right to subsidize in various regions. For example, a production project receives various forms of subsidies in different names, and the subsidy income. It is already greater than the actual cost expenditure, which will inevitably cause the impact of market commodity supply and disperse the financial strength of the country. Secondly, the fiscal management is loose. Financial subsidies are often only expressed as subsidies, but no effective follow-up inspections have resulted in the invisible loss of a large number of subsidies, which affects the scientific management of finance. Once again, the fiscal discipline is not strict, and there are no serious violations in the field of financial subsidies, such as false losses and fraudulent subsidies.

The expenditure standard for financial subsidies is unreasonable and lacks flexibility

Financial subsidies serve as a useful lever to implement government policy objectives and regulate economic development. According to the economic situation in different periods, the subsidy standards should be adjusted in a timely manner, and the policy, flexibility and timeliness of financial subsidy expenditure should be fully exerted, so that it can be limited within the controllable range of the state budget and financial resources to prevent the "rigidity" of subsidies. At present, due to the inadequate design of China's financial subsidy system, some subsidy expenditure projects have remained increasing throughout the year, which has led to some subsidy projects becoming long-term fiscal expenditure projects, which seriously violates the flexible 
principle of fiscal subsidy policies. At the same time, how to determine the specific standards of subsidies, how to evaluate the performance of subsidized projects, and other imperfections, also directly affect the effective arrangements of financial subsidies. The enterprise subsidy system is not standardized, and enterprise subsidies have serious over-reporting and false reporting. For example, in the absence of a reasonable and transparent pricing mechanism and effective subsidy mechanism, some state-owned financial policy subsidies often become the operating loss subsidies of enterprises. This often causes subsidies to be unevenly distributed among different enterprises and increases social injustice.

\section{Measures and recommendations for financial subsidy reform}

\section{Correct theoretical guidance and ideological understanding}

The normal functioning of the objective role of financial subsidies requires correct theoretical guidance and ideological understanding: First, the subsidies for the project can neither be subsidized too much at one time nor too little, and should be controlled within a certain range. Projects that do not need subsidies must be resolutely abolished. For those projects that need subsidies, the amount of subsidies should be controlled, the subsidies should be reversed from the state-sponsored situation, and the financial subsidies should be used rationally to leverage the subsidies in economic macroeconomic regulation. The positive role of China promotes the standardization of the country's financial order and creates superior conditions for the development of the social economy and the improvement of people's material living standards. Secondly, the benefits of subsidy activities should be market-oriented. Otherwise, investment cannot obtain the benefits and rewards. After the public finances are directly invested, the government will use the subsidy method to internalize the spillover benefits, thus reducing the financial burden. And will not violate the requirements of the market efficiency guidelines.

\section{Standardize the financial subsidy system and cancel the operating loss subsidy.}

There are two reasons for the existence of operating loss subsidies: First, excessive government intervention makes policy losses and operating losses indifferent; second, the government gives certain enterprises operating loss subsidies for social stability. The elimination of operating losses must be considered in two ways. First of all, to clarify the functions of the government, to separate government and enterprises, to reduce the intervention of enterprises, to separate the policy losses and operating losses of enterprises, and at the same time, to minimize the policy losses of enterprises through certain mechanisms, to completely eliminate the operational Loss subsidies and reduce policy loss subsidies, and secondly, reform and improve the social security system. Only by implementing a comprehensive social security system covering urban and rural areas, local governments will let the bankrupt enterprise go bankrupt, without having to subsidize the operating loss enterprises for the sake of social stability.

\section{Improving the financial subsidy policy}

Improve the efficiency of the implementation of fiscal subsidy policies, for example, to increase the enthusiasm of farmers to grow food, adopt the policy of direct subsidy, rely on the subsidy supervision and management mechanism, ensure the full payment of food subsidies, and establish cooperation between the financial department, the audit department and the agricultural department. The system prevents misappropriation of funds from misappropriation and deduction, and improves the efficiency of the implementation of fiscal subsidy policies. In addition, improve the financial risk compensation mechanism. For example, agricultural subsidies, the World Trade Organization requires member states to reduce agricultural subsidies, but the risk of natural disasters in agriculture is still not reduced, so the government can provide support measures for financial subsidies in the name of insurance by establishing a policy-based agricultural insurance system. Finally, the supervision and management mechanism of financial subsidy management is perfected. The policy model is used to regulate the use of subsidy project inspection, performance appraisal, subsidy funds, etc., while the scientific allocation model is used to standardize subsidy standards, such as open and transparent management mechanisms. To increase the full issuance of subsidy 
funds. In addition, measures to strengthen financial subsidy supervision are needed to improve the openness, impartiality and fairness in the implementation of subsidies.

\section{Incorporate financial subsidies into the track of legalization}

Since the reform and opening up, China has successively formulated a number of fiscal laws and administrative regulations, such as the budget law, the tax law and the state-owned assets management law, so that China's important financial activities have basically achieved legal compliance. However, in terms of financial subsidies, China is currently mainly adjusted by departmental regulations, and it is not authoritative and scientific. Therefore, in order to protect the legality and reasonableness of financial subsidies, corresponding laws and regulations should be formulated as soon as possible, and financial subsidies should be included in the track of legalization. The experience and shortcomings of long-term implementation of financial subsidies should be summarized, drafts should be drawn, and opinions should be widely sought from the public for continuous improvement. If we want to avoid social dissatisfaction, we must increase the transparency of subsidies, clarify and publicize the principles and standards of financial subsidies, so that the public can rationally supervise and judge.

\section{Conclusion}

In summary, China's financial subsidies serve as a lever for the government to regulate the economy. Financial subsidies play a role in regulating market supply and demand, promoting industrial policies, and promoting price reform. However, the scale of financial subsidies is large and the amount is so large that the normal economic order and the order of life are disrupted and negative negative effects begin to occur. This is extremely unreasonable for the social development itself, and even becomes the national finance. Tired, the main reason is the lack of understanding of financial subsidies, the irrational policies of financial subsidies, and the imperfect management of financial subsidies. Therefore, in terms of financial subsidy reform, China needs to establish a correct concept of financial subsidies, improve the policy of financial subsidies, strengthen the management of financial subsidies, and adapt to international trends in order to promote the standardization of the national financial order, for the socio-economic development and the people's material living standards. Improve and create superior conditions.

\section{References}

[1] Li Guanglong, Finance and Taxation [M]. Beijing: China Business Press, 2001.10.

[2] Chen Jiyu. Finance [M]. Changsha: Hunan People's Publishing House, 2002.11

[3] MeConnell, J.J.and H.Servaes.1990.Additional evidence on equity ownership and corporate value [J].Journal of Financial Economics, 27:595-612.

[4] Elyas Elyasiani, Jingyi Jane Jia.2008.Institutional ownership stability and BHC performance [J].Journal of Banking\&Finance, 32: 1767-1781.

[5] Zhang Xin. "Comparative Finance Course". Beijing; Renmin University of China Press, 1997 edition, 55, 129-131.81. Chen Houji. The Theory and Practice of Sustainable Agriculture and Rural Development-SARD. Beijing: China Agricultural Science and Technology Press, 1994 edition, 8-14, 288-291.

[6] Chen Houji. The international background proposed by SARD. World Agriculture, No. 2, 199S: 6-8.

[7] Chen Mengping. A comparative study of the financial support methods of the governments of developed countries. Economic Research Reference, No. 17 of 2000: 41-46. 